\title{
Gamma irradiation as suitable preservation method on herbal medicine: a review
}

\author{
${ }^{1,3}$ Hadiati, S.W., ${ }^{2}$ Winarno, H. and ${ }^{3, *}$ Pramono, S. \\ ${ }^{1}$ National Agency of Drug and Food Control of Indonesia, Jakarta 10560, Indonesia \\ ${ }^{2}$ Center for Isotopes and Radiation Applications, National Nuclear Energy Agency of Indonesia, Jakarta \\ 12440, Indonesia \\ ${ }^{3}$ Department of Pharmaceutical Biology, Faculty of Pharmacy, Universitas Gadjah Mada, Yogyakarta \\ 55281, Indonesia
}

\begin{abstract}
Article history:
Received: 3 November 2020

Received in revised form: 5

December 2020

Accepted: 16 February 2021

Available Online: 18 July

2021
\end{abstract}

\section{Keywords:}

Gamma irradiation,

Herbal Medicines

DOI:

https://doi.org/10.26656/fr.2017.5(5).494

\begin{abstract}
The trend of consuming herbal medicines has been increasing over the past three decades. No less than $80 \%$ of the world's population has used herbal medicines as a treatment. One of the problems in herbal medicine is the high level of microbial contamination caused by raw materials and production processes. Various attempts have been made to overcome these problems, one of them is the gamma irradiation method. Although irradiation has been widely used for food sterilization, the use of irradiation for sterilization on herbal medicines is still debated. It is because irradiation may affect the composition of active compounds of herbal medicines. This review aimed to discuss the applications of gamma irradiation for herbal medicines by emphasizing the chemical constituent stabilities of herbal medicines.
\end{abstract}

\section{Introduction}

The consumption of herbal medicines and supplements has been increasing rapidly over the past three decades. No less than $80 \%$ of people worldwide use herbal medicines for some parts of primary health care (Ekor, 2014). In 2014, the total global market of herbal products and medicinal plants were estimated at USD 33 billion with an annual average growth rate (AAGR) of $2.4 \%$ in volumes and $9.2 \%$ in values of export (Vasisht et al., 2016). With the increasing consumption of herbal products, it is important to assure the safety and quality of herbal products for consumers.

One of the main safety issues related to herbal medicines is contamination by various types of microorganisms, that may be present in the leaves, stems, flowers, seeds, and roots which are ingredients of herbal medicines. In a study of 91 herbal medicine samples in Brazil, Bugno et al. (2006) found that $50 \%$ of leaves and aerial part samples were contaminated with fungi, followed by flower samples $(16 \%)$ rhizomes and roots $(12 \%)$, barks $(12 \%)$ and seeds $(10 \%)$. Other studies showed that microbial contamination in herbal medicine has been found in China, South Africa, Palestine, Bangladesh, Malaysia and Indonesia (Ali et al., 2005; Noor et al., 2013; Ting et al., 2013; van Vuuren et al., 2014; Abualhasan et al., 2019).
In addition, microorganism contaminations can occur during the process of harvesting, handling, drying of open-air, preserving, and manufacturing (Lima et al., 2020). The risk of contamination often increases when harvesting is done in areas with very high humidity, rainy and dewy condition (WHO, 2003). The storage and condition process greatly determine the quality of the final herbal products. The problems are more commonly happen in tropical and subtropical areas, those are because the high temperature and moisture contents are encouraging fungal growth and toxin production (Zhang et al., 2012).

Various attempts have been made to decontaminate and preserve these medicinal plants to fulfil the requirement and obtain a safer, and more effective herbal medicine. Several methods of decontamination have been tried for decontaminating such as heat treatment, UV irradiation, fumigation, and gamma irradiation. However, heat treatment is not often possible because of the volatility and sensitivity of chemical compounds in medicinal plants, whereas UV irradiation is less effective due to the low energy penetration (Araujo and Bauab, 2012).

Since the use of irradiation was first approved by the U.S Food and Drug Administration (FDA) in 1963, the use of irradiation for food preservation purpose has eISSN: 2550-2166 / C 2021 The Authors. Published by Rynnye Lyan Resources 
increased rapidly (Stanley, 1997). In 2010, around 103,000 tons of foods are irradiated annually in the USA for human consumption included 80,000 tons of spices, 15,000 fruits and vegetables and 8,000 tons of poultry and meat, increased by 11,000 tons compared to 2005 . During five years (2005-2010), the amount of irradiated food in Asia increased by more than 55\%. China is the largest contributor in Asia with 70\% irradiated food followed by Vietnam at 23\%. In Indonesia, 6,923 tons of food were irradiated in 2010 comprised cocoa (80\%), frozen foods $(7 \%)$, spices $(5 \%)$ and other foods including dehydrated vegetables (Kume and Todoriki, 2013). Since 2017, Irradiator Gamma Merah Putih, one of the government irradiator facility in Indonesia, has provided food irradiation services at an average of 1,000 tons per year including food, spices and herbal products. Interestingly, the quantities of herbal irradiated are greater than food irradiated at this facility (Winarno, 2020).

The use of gamma irradiation for preserving herbal has been increasing, while it can reduce the level of microbial contamination effectively. In addition, gamma irradiation has the following advantages, namely cold process and strong penetrative power; it may be performed on the product as a final technological stage or final packaging; avoiding the possibility of recontamination or re-infestation; it can be applied to products through any type of packaging materials including paper, plastic, wood, etc.; environmentally friendly process (no use of pollutant agents, no generation of undesirable residual products, no penetration of toxic substances in treated products); it leads to safe products by effective expulsion of biological indicators; cheap and fast treatment (Ghisleni et al., 2016).

Although irradiation has been widely used for food sterilization, the use for sterilization of herbal medicines is still debated, because it may affect the composition of active compounds of herbal medicine. This review aims to discuss the applications of gamma irradiation for herbal medicines with an emphasis on the chemical constituent stability of herbal medicines.

\section{Regulations on herbal medicine irradiation}

According to International Atomic Energy Agency (IAEA), gamma irradiation is now permitted by over 60 countries (IAEA, 2020). Until now there is no specific regulation oversee the use of irradiation in herbal medicines, so it refers to food irradiation regulations. The regulations dictate how food is to be irradiated, what kind of foods are allowed to be treated, and the irradiation dose used are allowed. Regulations may vary greatly from country to country. Although there is agreement among international experts that food is safe to be consumed after irradiation up to a dose of $10 \mathrm{kGy}$, there is no agreement that this dose has a permitted limit for food irradiation in any country. Most countries approve food irradiation based on cases (Morehouse and Komolprasert, 2004)

The Codex Alimentarius Commission and IAEA released the international standards and regulations for irradiation of food. The Codex Alimentarius and IAEA made their resolution under the World Trade Organization (WTO) contract and agreement and they revealed that the member states could convert the standards into national regulations at their preference (Roberts, 2016).

Countries in the Asia Pacific region have harmonized regulations for food irradiation. At a regional meeting which was held in Seoul, Korea, in 1998, 13 representative countries agreed to adopt a harmonized regulation for food irradiation. The harmonized regulations were based on documents developed and adopted by the Association of Southeast Asian Nations (ASEAN) through the ASEAN ad hoc Working Group on Food Irradiation. The document contains the Model Regulations for Food Irradiation, which was prepared by the International Consultative Group on Food Irradiation (ICGFL) (Luckman, 2002). In Indonesia, regulation on Irradiated Food referred to Ministry of Health Regulation No.701/Menkes/Per/ VIII/2009 and Indonesia National Agency of Drug and Food Control Regulation No.3/2018. Based on the regulation, three approved sources of radiation process were Gamma irradiator with Co-60 or Cs-137 radioactive, X-ray with energy less than and equal to 7.5 $\mathrm{MeV}$ or Electron machine with energy less than equal to $10 \mathrm{MeV}$. The regulation also required the type of food that may be irradiated, the purpose of irradiation and the maximum allowable dose of irradiation (Ministry of Health of Indonesia, 2009; NADFC, 2018).

Irradiated food could not be recognized by sight, smell, taste, or touch. Thus, it needs to be given a specific label so that consumers know for certain that a food item has been irradiated. Since the 1960s, the symbol RADURA was used as a symbol for food processed by ionizing radiation. The RADURA is usually green in colour and resembles a plant in a circle. The upper half of the circle is dashed (Figure 1) (Codex, 1985; Ehlermann, 2009).

According to the Codex Alimentarius standard, the use of the RADURA-logo was voluntary. However, a few countries made its use mandatory, a few countries 
allow the optional use and others do not provide for the use of this international logo. In the Codex standard, the symbol was in green with all elements filled; some countries allow for different designs and even varying colours (Ehlermann, 2009). The FDA required labelling packaged irradiated foods sold in retail stores. All irradiated foods sold including fruits and vegetables also had to display a label. However, food products that contain irradiated ingredients, such as spices, did not need a label if it was not a whole product irradiated (Morehouse and Komolprasert, 2004). In Indonesia, irradiated packaged food had to include the word "IRADIASI" (irradiated) after the name of the food type. The label had to include the reason for irradiation and RADURA-logo. The name and address of the radiation facility, the month and year of the irradiation, and the country in which the process was carried out must be stated. If the food could not be re-irradiated, then the label should include the words: "TIDAK BOLEH DIRADIASI ULANG" (not to be re-irradiated) (NADFC, 2018).

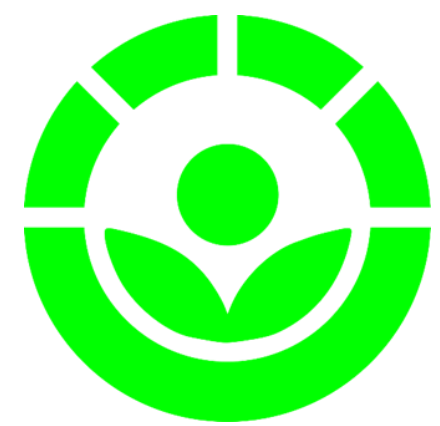

Figure 1. RADURA symbol

\section{Safety of gamma irradiation technology on herbal products}

Studies on the safety of gamma irradiation in herbal medicinal are still limited. However, the World Health Organization (WHO), the Food and Agriculture Organization of the United Nations (FAO), the U.S. Department of Agriculture (USDA), Health Canada (HC), the European Union (EU), and the Food and Drug Administration (FDA) has approved the safety of irradiated foods (Hazekamp, 2016).

To consider the possibility of the application of radiation technology for the Korean traditional medicinal herbs, the Geno-toxicological safety of the gammairradiated Paeoniae Radix were studied. The genotoxicity of the extract of the irradiated herb was examined in two short-term in vitro tests, there was Ames test in Salmonella typhimurium and the micronucleus test in cultured Chinese hamster ovary $(\mathrm{CHO})$ cells. The extract of the irradiated herb did not show mutagenicity in the Ames test of the Salmonella reverse mutation assay and did not show cytogenetic toxicity in the culture of the
$\mathrm{CHO}$ cells. These results suggested that gammairradiated Paeoniae Radix is toxicologically safe (Yu et al., 2004).

Toxicity tests were investigated to determine the safety of gamma irradiation on Zingiber cassumunar Roxb. Toxicity was estimated using Toxi-Chromo Test and accompanied by measurements of free radical content. Gamma irradiation doses 10 and $25 \mathrm{kGy}$ increased free radicals by 14.6 and 17.8 times, respectively. However, the toxic effect of irradiated samples was not significant compared to unirradiated. The results suggested that irradiation-induced free radicals did not cause enhancement of the toxicity (Thongphasuk et al., 2014).

\section{Mechanism of gamma-irradiation technology in inhibiting and killing microbes}

Several studies have shown that gamma-ray irradiation could reduce microbial contamination in herbal medicines. The effects of gamma irradiation on hygienic quality and extraction yields in twenty-one kinds of Korean medicinal herbs were investigated. Generally, moulds and yeasts, and coliforms required lower doses for the inactivation. Therefore, $10 \mathrm{kGy}$ of gamma irradiation reduced all microorganisms to below detection limits (Kim et al., 2000). Another study showed that seventeen species of herbs established in Thai traditional remedies were microbially decontaminated by gamma-irradiation doses of 7.7 and $8.8 \mathrm{kGy}$, while irradiation at dose 2.31 to $2.62 \mathrm{kGy}$ could reduce the microbial load at level $104 \mathrm{CFU} / \mathrm{g}$ in herbal cosmetics to meet the standard (less than $103 \mathrm{CFU} / \mathrm{g}$ ) (Phianphak et al. 2007; Neramitmansook et al., 2012). A study on four herbs and four herbal formulations in India showed gamma radiation dose of up to $10 \mathrm{kGy}$ could decontaminate microbes completely (Kumar et al., 2010). An irradiation dose of $2 \mathrm{kGy}$ was needed to sterilize Traditional Chinese Medicines (TCMs) in the form of powder, pills, and liquid bolus while the required dose to sterilize the bolus honey dosage form is $4 \mathrm{kGy}$ (Fang and $\mathrm{Wu}, 1998$ ).

The formation of endospores by bacteria could be considered an extreme response to a stress condition, such as oxidative stress, thermal stress, or chemical stress. Preservation method such as heat preservation and chemical preservation sometimes could not kill sporeforming bacteria effectively. Moreover, an alternative method was needed to solve this problem. The study on minced meat showed gamma irradiation dose $2 \mathrm{kGy}$ could be effective to kill spore-forming bacteria from $2.52 \log$ CFUg to undetected. This result suggests that gamma irradiation could be an alternative method to 
preserve food containing spore-forming bacteria (Khalafalla et al, 2018).

Microorganisms were inactivated when they were exposed to factors that substantially alter their cellular structure or physiological functions. Structural damage includes DNA strand breakage, cell membrane rupture or mechanical damage to the cell envelope. Cell functions were altered when key enzymes are inactivated or membrane selectivity is disabled (Lado and Yousef, 2002).

Herbal medicine was irradiated with irradiation would provide direct and indirect effects to the material that became the target. In this case, the target was irradiated microbes that contaminate herbal medicine. The indirect effects as an important part of the total action of radiation on microbes. Indirect action of irradiation occurred on the water as main the component of the cell. Irradiation produced hydroxyl radicals from water, which remove hydrogen atoms from the sugar and the bases of the DNA strands. Drying or freezing of living organisms could reduce these indirect effects (Borrely et al., 1998; Lado and Yousef, 2002).

Direct effects of the irradiation were the breaking of bonds of chains of DNA in cells of microbes so which might affect the ability of the cell to survive and multiply. DNA damaging events inflicted by irradiation include the deleterious alteration of bases and sugars, cross-link formation, single- and double-strand breaks (SSBs/DSBs), and DNA clustering (Reisz et al., 2014).

\section{Effect gamma-irradiation on phytochemical constituent}

\subsection{Effect of gamma irradiation on terpenoids}

Terpenoids, also known as isoprenoids or terpenes, are a large class of natural products found in nearly all living organisms. The majority of terpenoids are formed through the mevalonic acid (MVA) pathway, but they may also be formed through triose phosphate utilizing the non-mevalonate pathway (Brahmkshatriya and Brahmkshatriya, 2013). Terpenoids are formed by C5 isoprene units leading to their characteristic branchedchain structure. Terpenoids are divided into families based on the number of isoprene units from which they are formed there are hemiterpenoids (C5), monoterpenoids (C10), sesquiterpenoids (C15), diterpenoids (C20), sesterterpenoids (C25), triterpenoids (C30), tetraterpenoids (C40), and polyterpenes (longer chains of C5) (Kim et al., 2020).

Terpenoids are major constituents of essential oils produced by aromatic plants and tree resins. Commercially, terpenoids are produced in pharmaceutical and chemical industries and widely used as ingredients in perfumery, foods, cosmetics and personal care products, medicines, and a few other consumer applications (Leavell et al., 2016). Many terpenoids show pharmacology activities such as antimicrobial, antifungal, antiviral, antihyperglycemic, anti-inflammatory, antioxidants, antiparasitic, immunomodulatory, and skin permeation enhancer (Brahmkshatriya and Brahmkshatriya, 2013).

The effect of gamma-irradiation was limited to a reduction of some terpenes present in the cannabis, but keeping the terpene profile qualitatively the same. The main terpenes affected were the monoterpenes myrcene, cis-ocimene and terpinolene, and the sesquiterpenes gamma-selinene and eudesma-3,7(11)-diene. The terpenes were reduced but that no new compounds were formed in the cannabis due to irradiation, suggesting that the terpenes are evaporated during the process (Hazekamp, 2016).

Alloun et al. (2017) investigated effect of gamma irradiation on Thymus pallecens on the essential oil. The result showed no qualitative change was observed in the chemical composition for all sample. Gamma irradiation until 20 kGy slightly increases monoterpene hydrocarbons, on the other hand, decreases sesquiterpenes hydrocarbons with an irradiation dose of 10 kGy. A study on Angelica gigas showed the opposite result. Gamma irradiation decreases monoterpenes hydrocarbons caused by the reduction of $\alpha$-pinene contents, on the other hand, increase sesquiterpenes hydrocarbons. Both changes are not dependent on dose irradiation. Thus, the profile of composition volatiles of A. gigas did not change with irradiation (Seo et al., 2007).

Gamma irradiation effect on Piper nigrum volatile oil was investigated by Emam et al. (1995) showed gamma irradiation at doses of 5 and $10 \mathrm{kGy}$ could decrease the terpene hydrocarbons and increase the oxygenated group at the same time, especially alcohols such as Me-chavicol and eugenol, whereas $\alpha$ - and $\beta$ pinen, myrcene and $\alpha$-terpine decreased.

Yalcin, Ozturk, Tulukcu et al. (2011) studied the effect of gamma irradiation on the sage seed. Gamma irradiation at a dose of $7 \mathrm{kGy}$ decreased monoterpenes $\beta$ pinene and limonene of sage seed. Other studies on linseed oil showed that irradiation treatment resulted in a slight increase in limonene of irradiated sample at 5.5 kGy (Yalcin, Ozturk, Hayta et al., 2011).

Effect gamma irradiation after storage was investigated by Fan and Sokorai (2002). Fresh cilantro leaves (Coriandrum sativum L) were irradiated with 0,1 , 
2 , or $3 \mathrm{kGy}$ and then stored at $3^{\circ} \mathrm{C}$ for up to 14 days. The result showed that gamma irradiation at a dose of $3 \mathrm{kGy}$ reduced the content of terpenes such as myrcene and linalool at day 14 .

Irradiation might increase the terpenes content as increasing doses, but up to a certain limit. After that limit irradiation may cause a reduction in the amount of volatile compounds and vice versa. As an example, gamma irradiation increased the level of $\alpha$-Thujene on Piper nigrum volatile oil at dose $5 \mathrm{kGy}$ and decreased at $10 \mathrm{kGy}$ whereas eugenol was decreased at dose $5 \mathrm{kGy}$ and increase on $10 \mathrm{kGy}$ (Emam et al., 1995). Other studies on licorice showed that gamma irradiation decreased $\alpha$-Thujene was decreased at $10 \mathrm{kGy}$ and increase at $10 \mathrm{kGy}$ and vice versa for hexanol (Gyawali et al., 2008).

Terpenes, which are integrated into most of the essential oils, have the same skeleton structure but differ in their functional groups, such as $\mathrm{OH}, \mathrm{CHO}$, or $\mathrm{COOH}$. High doses irradiation can cause configurational changes, including changes in the positions of the double bonds and the functional groups to produce new compounds. These changes can be related to the irradiation effects on terpenes, such as oxidation or hydroxylation of the aromatic ring of terpenes. A low moisture content $(8-10 \%)$ in samples potentiates the direct and indirect effects of irradiation to increase the content of alcohols, which can generate free radicals from the water contained in spices. These radicals can react with terpenes to produce terpene oxides and terpene alcohols (Emam et al., 1995; Sadecka, 2010)

\subsection{Effect of gamma-irradiation on total phenolic content}

Phenolic compounds are a group of small molecules characterized by their structures having at least one phenol unit. Based on their chemical structures, phenolic compounds can be classified into different subgroups, such as phenolic acids, flavonoids, tannins, coumarins, lignans, quinones, stilbenes, and curcuminoids (Gan et al., 2018). Phenolic compounds are synthesized through the shikimic acid pathway, malonate-acetate pathway, and isoprenoid pathway (Stewart and Stewart, 2008). Phenolic compounds are known as natural antioxidants, thus have important properties in inhibition of lipid peroxidation, inhibition of carcinogenesis, antimicrobial activity, direct constrictive action on capillaries, naturally occurring phytohormones, stabilization of ascorbic acid, etc. (Tanase et al., 2019).

An increase in the amounts of total phenolics due to irradiation was reported by many authors. Researches with Nigella sativa, Carulluma tuberculate, Glycyrrhiza glabra, Curcuma alismatifolia, Thymus vulgaris, pistachio green hull, clove, nutmeg, soybean and almond skin, demonstrated this behaviour in the results (Variyar et al., 1998; Harrison and Were, 2007; Štajner et al., 2007; Khattak et al., 2008; Dixit et al., 2010; Khattak and Simpson, 2010; Taheri et al., 2014; Pereira et al., 2016; Shahzad et al., 2017; Abolhasani et al., 2018)

Harrison and Were (2007) suggested the increase in total phenolics content caused by gamma irradiation may attribute to the release of phenolic compounds from glycosidic components and degradation of larger phenolic compounds into smaller ones.

In contrast, another study reported a deceased of total phenolics on some plant. Koseki et al. (2002) reported a significant decrease in the amount of total phenolic compounds in dehydrated rosemary after irradiation at doses between 10 and $30 \mathrm{kGy}$, with respect to controls. Irradiation at dose until $10 \mathrm{KGy}$ on Aloysia citrodora also showed the same result (Pereira et al., 2017). The difference in the effects of irradiation on total phenolic content might be influenced by various factors such as the type and parts of the plant, phenolic content composition, environmental condition, solvent and method of extraction, storage conditions and irradiation dose (Harrison and Were, 2007; Khattak and Simpson, 2010).

\subsection{Effect of gamma-irradiation on total flavonoid content}

Flavonoids are a class of phenolic compounds presented broadly in plants. Flavonoids are known as colouring agents and contribute to the colourful pigments of fruits, herbs, vegetables and medicinal plants (Panche et al., 2016). Flavonoids are synthesized through the phenylpropanoid pathway, which transforming phenylalanine to 4-coumaroyl-CoA, then enters the flavonoid biosynthesis pathway. Chalcone synthase, the enzyme specific to the flavonoid pathway, produces chalcone scaffolds from which all flavonoids derive (Ferreyra et al., 2012).

Flavonoids are widely used in nutraceutical products, pharmaceuticals, medicines and cosmetics. Various studies have shown that flavonoids have antioxidant, anti -inflammatory, anti-mutagenic, and anti-carcinogenic properties and have the ability to modulate the function of major cellular enzymes. Flavonoids are also known as inhibitors for several enzymes, such as xanthine oxidase (XO), cyclo-oxygenase (COX), lipoxygenase and phosphoinositide 3-kinase (Panche et al., 2016).

Mun'im et al. (2017) reported that gamma irradiation dose of $10 \mathrm{kGy}$ reduced TFC significantly and caused degradation of flavonoids in Peperomia pelucida but slightly increased total phenolic content. Gamma 
irradiation also decreased the total flavonoid on Aloysia citrodora (Pereira et al., 2017). But the other studies showed contradictory results. Gamma irradiation increased total flavonoid contents on Curcuma alismatifolia and Thymus vulgaris (Taheri et al., 2014; Pereira et al., 2016). Irradiation might contribute to increase compounds extractability, on the other hand, it may also lead to degradation of some fewer stable compounds (Pereira et al., 2016).

\subsection{Effect of gamma-irradiation on others phytochemical constituent}

The effect of gamma irradiation on the curcuminoid component of turmeric (Curcuma domestica) was investigated by many researchers. Dhanya et al. (2011) reported curcuminoid on fresh peeled turmeric rhizomes was slightly increased by gamma irradiation at doses 5 $\mathrm{kGy}$. Gamma irradiation up to the dose of $10 \mathrm{kGy}$ under air atmosphere increased the curcuminoid content and total phenolics of turmeric powder (Esmaeili et al., 2018). Gamma irradiation doses up to $10 \mathrm{kGy}$ not significantly increased curcumin content but dose 15 kGy decreases the content significantly compare to unirradiated, therefore doses up to $10 \mathrm{kGy}$ should be applied to decontamination turmeric (Almeida et al., 2018). Another result also reported that the gamma irradiation at a dose of $10 \mathrm{kGy}$ could reduce the antiproliferative activity of fraction 3 of ethyl acetate extract from irradiated Curcuma xanthorrhiza rhizome against some human cancer cell lines, even though the reduction did not eliminate its antiproliferative activity (Winarno et al., 2019).

Effect gamma irradiation on alkaloids was reported by Darwis et al. (2020). The black pepper was exposed to Gamma irradiation at doses from 2 to $10 \mathrm{kGy}$. Irradiated pepper $(8 \mathrm{kGy})$ showed slightly higher piperine content compared to unirradiated pepper.

The effect of gamma irradiation on selected traditional Bulgarian teas was studied. Gamma irradiation increased the tannin content in Planinski tea and decreased it in Good Night tea (Janiak et al., 2017). Behgar et al. (2011) reported that gamma irradiation decreased tannin and antioxidant activity of pistachio hull extract. In contrast, the increase of tannin in soybean due to gamma irradiation was reported by Stajner et al. (2007). Gamma irradiation-induced tannin changes might be explained by molecular conversion, depolymerization, and cross-linking (de Camargo et al., 2015).

\section{Conclusion}

Gamma irradiation is a considered preservation alternative method of traditional medicine. It could decontaminate microbial without change phytochemical constituent on traditional medicine significantly. It concluded that gamma irradiation is a suitable method for the preservation and decontamination of herbal medicines.

\section{Conflict of interest}

The authors declare no conflict of interest.

\section{Acknowledgements}

The first author extends thank to the National Agency of Drug and Food Control of Indonesia for the valuable suggestions and support.

\section{References}

Abolhasani, A., Barzegar, M. and Sahari, M.A. (2018). Effect of gamma irradiation on the extraction yield, antioxidant, and antityrosinase activities of pistachio green hull extract. Radiation Physics and Chemistry, 144, 373-378. https://doi.org/10.1016/ j.radphyschem.2017.09.025

Abualhasan, M., Jaradat, N., Sawaftah, Z., Mohsen, H., Najjar, D. and Zareer, W. (2019). Evaluation of Heavy Metals and Microbiological Contamination of Selected herbals from Palestine. Open Life Sciences, 14(1), 448-453. https://doi.org/10.1515/biol-20190050

Ali, N., Hashim, N. H., Saad, B., Safan, K., Nakajima, M. and Yoshizawa, T. (2005). Evaluation of a method to determine the natural occurrence of aflatoxins in commercial traditional herbal medicines from Malaysia and Indonesia. Food and Chemical Toxicology, 43(12), 1763-1772. https:// doi.org/10.1016/j.fct.2005.05.019

Alloun, K., Benchabane, O., Hazzit, M., Mouhouche, F. and Baaliouamer, A. (2017). Effect of Gamma Ray Irradiation on Chemical Composition, Antioxidant, Antimicrobial, and Insecticidal Activities of Thymus pallescens Essential Oil. Acta Chromatographica, 31 (1), 1-6. https://doi.org/10.1556/1326.2017.00346

Almeida, M.C., Sampaio, G.R., Bastos, D.H.M. and Villavicencio, A.L.C.H. (2018). Effect of gamma radiation processing on turmeric: Antioxidant activity and curcumin content. Radiation Physics and Chemistry, 152, 12-16. https://doi.org/10.1016/ j.radphyschem.2018.07.008

Araujo, M.G.D.F. and Bauab T.M. (2012). Microbial Quality of Medicinal Plant Materials. In Akyar, I. (Ed). Latest Research into Quality Control. Intech Open E-book. https://doi.org/10.5772/51072 
Behgar, M., Ghasemi, S., Naserian, A., Borzoie, A. and Fatollahi, H. (2011). Gamma radiation effects on phenolics, antioxidants activity and in vitro digestion of pistachio (Pistachia vera) hull. Radiation Physics and Chemistry, 80(9), 963-967. https:// doi.org/10.1016/j.radphyschem.2011.04.016

Borrely, S.I., Cruz, A.C., del Mastro, N.L., Sampa, M.H.O. and Somessari, E.S. (1998). Radiation processing of sewage and sludge. A review. Progress in Nuclear Energy, 33(1-2), 3-21. https:// doi.org/10.1016/S0149-1970(97)87287-3

Brahmkshatriya, P.P. and Brahmkshatriya, P.S. (2013). Terpenes: Chemistry, biological role, and therapeutic applications. In Ramawat, K.G. and Me'rillon, J.M. (Eds). Natural Products: Phytochemistry, Botany and Metabolism of Alkaloids, Phenolics and Terpenes, $p$. 2665-2691. Berlin Heidelberg, Germany: Springer. https://doi.org/10.1007/978-3-642-22144-6_120

Bugno, A., Buzzo Almodovar, A.A., Pereira, T.C., Andreoli Pinto, T.D.J. and Sabino, M. (2006). Occurrence of toxigenic fungi in herbal drugs. Brazilian Journal of Microbiology, 37(1), 47-51. https://doi.org/10.1590/S1517-83822006000100009

Codex Alimentarius. (1985). Labelling of Prepackaged Foods (CODEX STAN 1-1985). Retrieved from http://www.fao.org/3/Y2770E/y2770e02.htm.

Darwis, D., Puspitasari, T., Nuryanthi, N. and Kadir, I. (2020). Improvement of Bangka's white pepper quality using gamma irradiation technology: microbial contamination reduction. Journal of Physics: Conference Series, 1436, 012010. https:// doi.org/10.1088/1742-6596/1436/1/012010

de Camargo, A.C., Regitano-d'Arce, M.A.B., Gallo, C.R. and Shahidi, F. (2015). Gamma-irradiation induced changes in microbiological status, phenolic profile and antioxidant activity of peanut skin. Journal of Functional Foods, 12, 129-143. https:// doi.org/10.1016/j.jff.2014.10.034

Dhanya, R., Mishra, B.B. and Khaleel, K.M. (2011). Effect of gamma irradiation on curcuminoids and volatile oils of fresh turmeric (Curcuma longa). Radiation Physics and Chemistry, 80(11), 12471249. j.radphyschem.2011.05.010

Dixit, A.K., Bhatnagar, D., Kumar, V., Rani, A., Manjaya, J.G. and Bhatnagar, D. (2010). Gamma Irradiation Induced Enhancement in Isoflavones, Total Phenol, Anthocyanin and Antioxidant Properties of Varying Seed Coat Coloured Soybean. Journal of Agricultural and Food Chemistry, 58(7), 4298-4302. https://doi.org/10.1021/jf904228e

Ehlermann, D.A.E. (2009). The RADURA-terminology and food irradiation. Food Control, 20(5), 526-528. https://doi.org/10.1016/j.foodcont.2008.07.023

Ekor, M. (2014). The growing use of herbal medicines: Issues relating to adverse reactions and challenges in monitoring safety. Frontiers in Pharmacology, 4, 177. https://doi.org/10.3389/fphar.2013.00177

Emam, O.A., Farag, S.A. and Aziz, N.H. (1995). Comparative Effects of Gamma and Microwave Irradiation on the Quality of Black Pepper. Z Lebensm Unters Forsch, 201(6), 557-561. https:// doi.org/10.1007/BF01201585

Esmaeili, S., Barzegar, M., Sahari, M.A. and BerengiArdestani, S. (2018). Effect of gamma irradiation under various atmospheres of packaging on the microbial and physicochemical properties of turmeric powder. Radiation Physics and Chemistry, 148, 60-67. https://doi.org/10.1016/ j.radphyschem.2018.02.028

Fan, X. and Sokorai, K.J.B. (2002). Changes in volatile compounds of $\gamma$-Irradiated fresh cilantro leaves during cold storage. Journal of Agricultural and Food Chemistry, 50(26), 7622-7626. https:// doi.org/10.1021/jf020584j

Fang, X. and $\mathrm{Wu}$, J. (1998). Feasibility of sterilizing traditional Chinese medicines by Gamma-Irradiation. Radiation Physics and Chemistry, 52(1-6), 53-58. https://doi.org/10.1016/S0969-806X(98)00073-5

Ferreyra, F.F.M.L., Rius, S.P. and Casati, P. (2012). Flavonoids: Biosynthesis, biological functions, and biotechnological applications. Frontiers in Plant Science, 3, 222. https://doi.org/10.3389/ fpls.2012.00222

Gan, R.Y., Chan, C.L., Yang, Q.Q., Li, H.B., Zhang, D., Ge, Y.Y., Gunaratne, A., Ge, J. and Corke, H. (2018). Bioactive compounds and beneficial functions of sprouted grains. In Feng, H., Nemzer, B. and DeVries, J.W. (Eds). Sprouted Grains: Nutritional Value, Production, and Applications, p. 191-246. USA: AACC International Press. https:// doi.org/10.1016/B978-0-12-811525-1.00009-9

Ghisleni, D.D.M., Braga, M.D.S., Kikuchi, I.S., Braşoveanu, M., Nemţanu, M.R., Dua, K. and Pinto, T.D.J.A. (2016). The microbial quality aspects and decontamination approaches for the herbal medicinal plants and products: an in-depth review. Current Pharmaceutical Design, 22(27), 4264-4287. https:// doi.org/10.2174/1381612822666160623070829

Gyawali, R., Seo, H.Y. and Shim, S.L. (2007). Effect of $\gamma$-irradiaton on the volatile compounds of licorice (Glycyrrhiza uralensis Fischer). European Food Research and Technology, 226(3), 577-582. https:// doi.org/10.1007/s00217-007-0591-2 
Harrison, K. and Were, L.M. (2007). Food Chemistry Effect of gamma irradiation on total phenolic content yield and antioxidant capacity of Almond skin extracts. Food Chemistry, 102(3), 932-937. https:// doi.org/10.1016/j.foodchem.2006.06.034

Hazekamp, A. (2016). Evaluating the Effects of GammaIrradiation for Decontamination of Medicinal Cannabis. Frontiers in Pharmacology, 7, 108. https://doi.org/10.3389/fphar.2016.00108

International Atomic Energy Agency (IAEA). (2020). Food irradiation, benefits, use, standards. Retrieved on June 18, 2020, from IAEA Website: https:// www.iaea.org/topics/food-irradiation

Janiak, M.A., Slavova-Kazakova, A., Karamać, M., Kancheva, V., Terzieva, A., Ivanova, M., Tsrunchev, T. and Amarowicz, R. (2017). Effects of gammairradiation on the antioxidant potential of traditional Bulgarian teas. Natural Product Communications, 12 (2), 181-184. doi.org/10.1177/1934578X1701200210 https://

Khalafalla, G.M., Nasr, F.N., Gaafar, A.M. and AboZaid, A.M. (2018). Effect of gamma irradiation on microbial load, physicochemical characteristics and shelf-life of raw minced beef meat. Middle East Journal of Applied Sciences, 8(2), 625-634.

Khattak, F.K. and Simpson, J.T. (2010). Effect of gamma irradiation on the antimicrobial and free radical scavenging activities of Glycyrrhiza glabra root. Radiation Physics and Chemistry, 79(4), 507512. https://doi.org/10.1016/ j.radphyschem.2009.10.005

Khattak, F.K., Simpson, J.T. and Ihasnullah. (2008). Effect of gamma irradiation on the extraction yield, total phenolic content and free radical-scavenging activity of Nigella sativa seed. Food Chemistry, 110 (4), 967-972. https://doi.org/10.1016/ j.foodchem.2008.03.003

Kim, M.J., Yook, H.S. and Byun, M.W. (2000). Effects of gamma irradiation on microbial contamination and extraction yields of Korean medicinal herbs. Radiation Physics and Chemistry, 57(1), 55-58. https://doi.org/10.1016/S0969-806X(99)00298-4

Kim, T., Song, B., Cho, K.S. and Lee, I.S. (2020). Therapeutic potential of volatile terpenes and terpenoids from forests for inflammatory diseases. International Journal of Molecular Sciences, 21(6), 2187. https://doi.org/10.3390/ijms21062187

Koseki, P.M., Anna, L., Villavicencio, C.H., Brito, S., Almeida-muradian, L.B., Mancini-filho, J. and Freitas, P.C.D. (2002). Effects of irradiation in medicinal and eatable herbs. Radiation Physics and Chemistry, 63(3-6), 681-684. https://
doi.org/10.1016/S0969-806X(01)00658-2

Kumar, S., Gautam, S., Powar, S. and Sharma, A. (2010). Microbial decontamination of medicinally important herbals using gamma radiation and their biochemical characterization. Food Chemistry, 119 (1), 328-335. https://doi.org/10.1016/ j.foodchem.2009.06.034

Kume, T. and Todoriki, S. (2013). Food Irradiation in Asia, the European Union and the United States: A Status Update. Radioisotopes, 62(5), 291-299. https://doi.org/10.3769/radioisotopes.62.291

Lado, B.H. and Yousef, A.E. (2002). Alternative foodpreservation technologies: Efficacy and mechanisms. Microbes and Infection, 4(4), 433-440. https:// doi.org/10.1016/S1286-4579(02)01557-5

Leavell, M.D., McPhee, D.J. and Paddon, C.J. (2016). Developing fermentative terpenoid production for commercial usage. Current Opinion in Biotechnology, 37,114-119. https://doi.org/10.1016/ j.copbio.2015.10.007

Lima, d.SC.M., Fujishima, M.A.T., de Paula Lima, B., Mastroianni, P.C., de Sousa, F.F.O. and da Silva, J.O. (2020). Microbial contamination in herbal medicines: a serious health hazard to elderly consumers. BMC Complementary Medicine and Therapies, 20(1), 1-9. https://doi.org/10.1186/ s12906-019-2723-1

Luckman, G.J. (2002). Food irradiation: regulatory aspects in the Asia and Pacific region. Radiation Physics and Chemistry, 63(3-6), 285-288. https:// doi.org/10.1016/S0969-806X(01)00625-9

Ministry of Health of Indonesia. (2009). Peraturan Menteri Kesehatan Republik Indonesia Nomor 701/ MENKES/PER/VIII/2009 Tentang Pangan Iradiasi. Retrieved on August 28, 2009 from: https:// www.jdih.pom.go.id. [In Bahasa Indonesia].

Morehouse, K.M. and Komolprasert, V. (2004). Overview of Irradiation of Food and Packaging | FDA. ACS Symposium Series 875 Irradiation of Food and Packaging. Retrieved on June 17, 2020, from FDA website: https://www.fda.gov/food/ irradiation-food-packaging/overview-irradiationfood-and-packaging

Mun'im, A., Ramadhani, F., Chaerani, K., Amelia, L., and Arrahman, A. (2017). Effects of gamma irradiation on microbiological, phytochemical content, antioxidant activity and inhibition of Angiotensin Converting Enzyme (ACE) activity of Peperomia pellucida (L.) Kunth. Journal of Young Pharmacists, 9(1 Supplement), s65-s69. https:// doi.org/10.5530/jyp.2017.1s.17

National Agency of Drug and Food Control (NADFC). 
(2018). Peraturan Badan Pengawas Obat dan Makanan Republik Indonesia Nomor 3 Tahun 2018 Tentang Pangan Iradiasi, Retrieved on May 7, 2018 from: https://www.jdih.pom.go.id. [In Bahasa Indonesia].

Neramitmansook, N., Chahorm, K., Prakhongsil, P., Phianphak, W. and Keawchoung, P. (2012). Application of gamma irradiation to reduce microbial contamination in herbal cosmetic products. Radiation Physics and Chemistry, 81(8), 1189-1192. https://doi.org/10.1016/j.radphyschem.2011.11.002

Noor, R., Huda, N., Rahman, F. and Munshi, S.K. (2013). Microbial contamination in herbal medicines available in Bangladesh. Bangladesh Medical Research Council Bulletin, 39(3), 124-129. https:// doi.org/10.3329/bmrcb.v39i3.20313

Panche, A.N., Diwan, A.D. and Chandra, S.R. (2016). Flavonoids: An overview. Journal of Nutritional Science, 5(47), 1-15. https://doi.org/10.1017/ jns. 2016.41

Pereira, E., Barros, L., Antonio, A.L., Cabo Verde, S., Santos-Buelga, C. and Ferreira, I.C.F.R. (2016). Infusions from Thymus vulgaris L. treated at different gamma radiation doses: Effects on antioxidant activity and phenolic composition. $L W T$ Food Science and Technology, 74, 34-39. https:// doi.org/10.1016/j.lwt.2016.07.027

Pereira, E., Barros, L., Antonio, A.L., Verde, S.C., Santos-buelga, C., Ferreira, I.C.F.R. and Rodrigues, P. (2017). Is Gamma Radiation Suitable to Preserve Phenolic Compounds and to Decontaminate Mycotoxins in Aromatic Plants? A Case-Study with Aloysia citrodora Pal. Molecules, 22(23), 347. https://doi.org/10.3390/molecules22030347

Phianphak, W., Rengpipat, S. and Cherdshewasart, W. (2007). Gamma Irradiation versus Microbial Contamination of Thai Medicinal Herbs. Songklanakarin Journal of Science and Technology, 29(Supplement 1), 157-166.

Reisz, J.A., Bansal, N., Qian, J., Zhao, W. and Furdui, C.M. (2014). Effects of ionizing radiation on biological molecules - mechanisms of damage and emerging methods of detection. Antioxidants and Redox Signaling, 21(2), 260-292. https:// doi.org/10.1089/ars.2013.5489

Roberts, P.B. (2016). Food irradiation: Standards, regulations and worldwide trade. Radiation Physics and Chemistry, 129, 30-34. https://doi.org/10.1016/ j.radphyschem.2016.06.005

Sadecka, J. (2010). Influence of Two Sterilization Ways, Gamma-Irradiation and Heat Treatment, on the Volatiles of Black Pepper. Czech Journal Food
Science, 28(1), 44-52. https://doi.org/10.17221/1325 -CJFS

Seo, H., Kim, J., Song, H., Kim, D., Byun, M., Kwon, J. and Kim, K. (2007). Effects of gamma irradiation on the yields of volatile extracts of Angelica gigas Nakai. Radiation Physics and Chemistry, 76(11-12), 1869-1874.

https://doi.org/10.1016/

j.radphyschem.2007.03.020

Shahzad, N., Elahi, R. and Ali, S. (2017). Effect of Gamma Irradiation on Phytochemical Content and Antimicrobial Activities of Selected Herbs. Austin Journal of Nutrition and Food Sciences, 5(3), 1-15.

Štajner, D., Miloševi, M. and Popovi, B.M. (2007). Irradiation Effects on Phenolic Content, Lipid and Protein Oxidation and Scavenger Ability of Soybean Seeds. International Journal of Molecular Sciences, 8(7), 618-627. https://doi.org/10.3390/i8070618

Stanley, D. (1997). BACKGROUNDER: Food Irradiation. Retrieved on July 20, 2020 from USDA website: https://www.ars.usda.gov/news-events/ news/research-news/1997/backgrounder-foodirradiation/

Stewart, A.J. and Stewart, R.F. (2008). Phenols. In Jorgensen, S.V. and Fath, B.D. (Eds). Encyclopedia of Ecology, p. 2682-2689. USA: Academic Press. https://doi.org/10.1016/B978-008045405-4.00417-1

Taheri, S., Abdullah, T.L., Karimi, E. and Oskoueian, E. (2014). Antioxidant capacities and total phenolic contents enhancement with acute gamma irradiation in Curcuma alismatifolia (Zingiberaceae) Leaves. International Journal of Molecular Sciences, 15(7), 13077-13090. https://doi.org/10.3390/ ijms 150713077

Tanase, C., Cosarcă, S. and Muntean, D.L. (2019). A critical review of phenolic compounds extracted from the bark of woody vascular plants and their potential biological activity. Molecules, 24(6), 1182. https://doi.org/10.3390/molecules24061182

Thongphasuk, P., Thongphasuk, J., Bavovada, R. and Chalmulitrat, W. (2014). Effects of gamma irradiation on active components, free radicals and toxicity of cassumunar ginger rhizomes. International Journal of Pharmacy and Pharmaceutical Sciences, 6(7), 432-436.

Ting, A., Chow, Y. and Tan, W. (2013). Microbial and heavy metal contamination in commonly consumed traditional Chinese herbal medicines. Journal of Traditional Chinese Medicine, 33(1), 119-124. https://doi.org/10.1016/S0254-6272(13)60112-0

van Vuuren, S., Williams, V.L., Sooka, A., Burger, A. and van der Haar, L. (2014). Microbial contamination of traditional medicinal plants sold at 
the Faraday muthi market, Johannesburg, South Africa. South African Journal of Botany, 94, 95-100. https://doi.org/10.1016/j.sajb.2014.06.002

Variyar, P.S., Bandyopadhyay, C. and Thomas, P. (1998). Effect of gamma-irradiation on the phenolic acids of some Indian spices. International Journal of Food Science and Technology, 33(6), 533-537. https://doi.org/10.1046/j.1365-2621.1998.00219.x

Vasisht, K., Sharma, N. and Karan, M. (2016). Current Perspective in the International Trade of Medicinal Plants Material: An Update. Current Pharmaceutical Design, 22(27), 4288-4336. https:// doi.org/10.2174/1381612822666160607070736

Winarno, E.K., Winarno, H. and Susanto. (2019). Antiproliferative Activity of Extracts and Fractions from Irradiated Curcuma xanthorrizha Rhizome Against Mouse Leukemia and Human Cancer Cell Lines. Atom Indonesia, 45(3), 159-164. https:// doi.org/10.17146/aij.2019.957

Winarno, H. (2020). Teknologi Penanganan Pasca Panen Menggunakan Iradiasi, presented at online Conference "Pemanfaatan Teknologi Radiasi untuk Meningkatkan Daya Saing Komoditas Pangan, Badan Tenaga Nuklir Nasional. Jakarta. Indonesia. [In Bahasa Indonesia].

World Health Organization (WHO). (2003). WHO guidelines on good agricultural and collection practices (GACP) for medicinal plants. Retrieved on June 18, 2020, from WHO website: https://www. https://apps.who.int/iris/handle/10665/42783

Yalcin, H., Ozturk, I., Hayta, M., Sagdic, O. and Gumus, T. (2011). Effect of Gamma-Irradiation on some chemical characteristics and volatile content of linseed. Journal of Medicinal Food, 14(10), 12231228. https://doi.org/10.1089/jmf.2010.0249

Yalcin, H., Ozturk, I., Tulukcu, E. and Sagdic, O. (2011). Effect of $\gamma$-Irradiation on bioactivity, fatty acid compositions and volatile compounds of clary sage seed (Salvia sclarea L.). Journal of Food Science, 76 (7), 1056-1061. https://doi.org/10.1111/j.17503841.2011.02331.x

Yu, Y.B., Jeong, I.Y., Park, H.R., Oh, H., Jung, U. and Jo, S.K. (2004). Toxicological safety and stability of the components of an irradiated Korean medicinal herb, Paeoniae Radix. Radiation Physics and Chemistry, 71(1-2), 117-121. https:// doi.org/10.1016/j.radphyschem.2004.04.002

Zhang, J., Wider, B., Shang, H., Li, X. and Ernst, E. (2012). Quality of herbal medicines: Challenges and solutions. Complementary Therapies in Medicine, 20 (1-2),100-106. https://doi.org/10.1016/ j.ctim.2011.09.004 